\title{
CORCHORUS OLITORIUS AND URTICA PILULIFERA EXTRACTS ALLEVIATE COPPER INDUCED OXIDATIVE DAMAGE AND GENOTOXICITY IN TOMATO
}

\author{
Özlem Darcansoy İșeri, ${ }^{1,2 *}$ Didem AKsoy KöRPe, ${ }^{1}$ \\ FERIDE IfFEt SAHIN ${ }^{1,3}$ and MeHMet HaberaL ${ }^{1,4}$ \\ ${ }^{1}$ Institute of Transplantation and Gene Sciences, Baskent University, Ankara, Turkey \\ 2Department of Molecular Biology and Genetics, Faculty of Science and Letters, Baskent University, \\ Ankara, Turkey \\ ${ }^{3}$ Department of Medical Genetics, Faculty of Medicine, Baskent University, Ankara, Turkey \\ ${ }^{4}$ Department General Surgery, Faculty of Medicine, Baskent University, Ankara, Turkey
}

(Received: April 18, 2018; accepted: June 19, 2018)

\begin{abstract}
Copper cause oxidative damage in plant cells, and plant extracts are the sources of free radical scavengers. We tested the hypothesis that whether Corchorus olitorius (jute) and Urtica pilulifera (Roman nettle) seed extract treatments of germinated seeds affect copper induced oxidative and genotoxic damage or antioxidant response in tomato. Seedlings were exposed to toxic copper concentration (30 ppm) for 7 days. In one experimental group (treatment 1$)$, extract $\left(100 \mu \mathrm{g} \mathrm{mL}^{-1}\right)$ was added to media. In the other group (treatment 2), tomato seeds were pre-soaked by the extract $\left(100 \mu \mathrm{g} \mathrm{mL}^{-1}\right)$ prior to germination and copper application. Malondialdehyde and endogenous $\mathrm{H}_{2} \mathrm{O}_{2}$ levels in the groups treated with extract and copper were significantly lower than that of the untreated groups. Pre-soaking seeds with the nettle extract solution significantly enhanced catalase activity under unstressed condition. Jute treatment also enhanced catalase activity under copper stress. Ascorbate peroxidase activity remained at unstressed level in copper treated groups. Extract treatments significantly decreased copper induced DNA damage in root nuclei. Jute seed extract contained salicylic acid and quercetin which can be correlated with the evoked effects. We demonstrated protective effect of plant extract treatments against copper stress of tomato seedlings prior to germination or during seedling development.
\end{abstract}

Keywords: Copper stress - Solanum lycopersicum - jute - Roman nettle - genotoxic damage

\section{INTRODUCTION}

Besides being a micronutrient for normal growth and development of plants, copper $(\mathrm{Cu})$ at higher concentrations can cause multiple toxic effects at physiological, biochemical, and genetic levels. Previously, we demonstrated a concentration-dependent inhibition of root growth of Solanum lycopersicum (tomato) and Cucumis sativus (cucumber), increased ROS, enhanced enzymatic antioxidant response, and $\mathrm{Cu}^{2+}$ induced oxidative and genotoxic damage in root cells nuclei [14]. Copper accumulation can also cause alterations in vital processes of plants such as mineral nutrition, photosynthesis, enzyme activities, and biosynthesis of various macromolecules,

*Corresponding author; e-mail addresses: oiseri@gmail.com, odiseri@baskent.edu.tr 
including chlorophyll, leading to the inhibition of seed germination, growth, and development $[8,22]$.

In our previous studies, we have reported for the first time high antibacterial activity of Urtica pilulifera L. (Roman nettle) extracts against phytopathogenic bacteria [20]. In addition, high free radical scavenging activities and total phenol content of the extracts were also demonstrated $[15,20]$. We have also studied the allelopathic effects of the Corchorus olitorius L. (jute) and U. pilulifera seed extracts on tomato seed germination and vigour [14]. Corchorus olitorius L. has industrial importance in world's jute production besides its agricultural importance as a widely cultivated and consumed crop in Cyprus and some Arabic countries. Urtica spp. (nettles) are annual or perennial herbaceous plants growing in the borders of fields, roads, and forests.

Based on the facts that copper causes oxidative damage to plant cells and plant extracts are the sources of free radical scavengers, in this study, we tested the hypothesis that whether extract treatments of germinated seeds affect copper induced oxidative and genotoxic damage or antioxidant response. We exposed germinated seeds to $\mathrm{EC}_{50}$ of $\mathrm{Cu}^{2+}(30 \mathrm{ppm})$ [13], and evaluated copper induced cytotoxicity and genotoxicity in terms of oxidative damage, hydrogen peroxide levels, ascorbate peroxidase (APX; EC 1.11.1.11) and catalase (CAT; EC 1.11.1.6) activity levels, and DNA tail moment measurements of Comet assays.

\section{MATERIALS AND METHODS}

\section{Plant materials and extractions}

Urtica pilulifera L. were cultured from seeds in the Institute of Transplantation and Gene Sciences, Baskent University (Kazan-Ankara, Turkey). Seeds of Corchorus olitorius L. were collected from Nicosia, Cyprus. Voucher specimens were authenticated by Assoc. Prof. Dr. Evren Cabi (Department of Biology, Namık Kemal University, Tekirdağ, Turkey), and stored as herbarium materials. Extracts were prepared as previously described [15,20]. In brief, 10 grams of seed powders was mixed with $100 \mathrm{~mL}$ of pure methanol (MetOH; Merck, Germany), and incubated at room temperature (dark) with continuous shaking for $24 \mathrm{~h}$. Filtrates were lyophilized by using a freeze-dryer at $-50{ }^{\circ} \mathrm{C}, 0.50 \mathrm{hPa}$ (LyoPro 3000, Thermo Scientific Heto, USA). Dry material was re-suspended in dimethyl sulfoxide (Sigma-Aldrich, USA) to have $200 \mathrm{mg} \mathrm{mL}^{-1}$ of stock extract solutions, and stored at $-20^{\circ} \mathrm{C}$.

Phenolic compounds in the $C$. olitorius seed extract were quantitatively analyzed by high performance liquid chromatography coupled with mass spectrometer (HPLCTOF-MS; Agilent Technologies 1260 Infinity LC, 6210 TOF-MS) at the Department of Chemistry, Çankırı University (Çankırı, Turkey). In brief, $10 \mu \mathrm{L} 200 \mathrm{ppm}$ samples were injected to ZORBAX SB-C18 column $(4.6 \times 100 \mathrm{~mm}, 3.5 \mu \mathrm{m})$ through a 0.45 $\mu \mathrm{m}$ filter at $35^{\circ} \mathrm{C}$ column temperature. Mass to charge ratio $\left(\mathrm{m} \mathrm{z}^{-1}\right)$ and retention time analysis of the extract components with 23 standard phenolic compounds (Table 1) were performed. 
Table 1

Quantitative analysis of phenolics of C. olitorius seed extract by HPLC-TOF

\begin{tabular}{|l|c|c|c|}
\hline \multicolumn{1}{|c|}{ Compound } & Retention time (min) & Mass/charge $\left(\mathrm{m} \mathrm{z}^{-1}\right)$ & $\begin{array}{c}\text { C. olitorius extract } \\
\left(\mu \mathrm{g} \mathrm{g}^{-1}\right)\end{array}$ \\
\hline Gallic acid & 2.55 & 169.01 & 5.41 \\
\hline Gentisic acid & 4.27 & 153.02 & nd \\
\hline Catechin & 6.29 & 289.07 & nd \\
\hline Chlorogenic acid & 6.30 & 353.08 & nd \\
\hline 4-Hydroxybenzoic acid & 6.67 & 137.02 & nd \\
\hline Protocatechuic acid & 6.80 & 153.02 & nd \\
\hline Caffeic acid & 7.64 & 179.03 & nd \\
\hline Vanillic acid & 7.77 & 167.03 & 69.70 \\
\hline 4-Hydroxybenzaldehyde & 8.96 & 121.03 & nd \\
\hline Rutin & 9.90 & 609.14 & nd \\
\hline Chcoric acid & 10.02 & 473.07 & nd \\
\hline$p$-Coumaric acid & 10.20 & 163.04 & nd \\
\hline Ellagic acid & 10.03 & 300.99 & nd \\
\hline Ferulic acid & 10.93 & 193.05 & nd \\
\hline Hesperidin & 11.88 & 609.18 & nd \\
\hline Apigenin 7-glucoside & 11.91 & 431.09 & nd \\
\hline Rosmarinic acid & 12.54 & 359.07 & 0.65 \\
\hline Protocatechuic acid ethyl ester & 13.48 & 181.05 & nd \\
\hline Salicylic acid & 13.62 & 137.02 & 2.23 \\
\hline Resveratrol & 14.16 & 227.07 & nd \\
\hline Quercetin & 15.46 & 301.03 & 0.52 \\
\hline Naringenin & 17.53 & 271.07 & nd \\
\hline Kamperol & 17.98 & 285.04 & \\
\hline Total value & & & \\
\hline
\end{tabular}

*nd: not detected.

\section{Seed treatments}

Surface sterilized Solanum lycopersicum L. commercial cv. H2274 (MayAgro Seed Corporation, Turkey) seeds were used in the experiments. Experimental setup is presented in Fig. 1. Twenty germinated seeds for each replicate were transferred to sterile 1/2 strength Hoagland's nutrient solution (Sigma, USA). All the groups contained at least 4 replicates. Treatment groups contained $100 \mu \mathrm{g} \mathrm{mL}^{-1}$ jute or nettle 
extracts in the Hoagland's solution (treatment 1), or seeds were pre-soaked into 100 $\mu \mathrm{g} \mathrm{mL}-1$ jute or nettle extract solutions (treatment 2) for $24 \mathrm{~h}$ prior to germination. Seedlings were incubated at $23-25^{\circ} \mathrm{C}$, at dark, by shaking. Then, the seeds were left to germinate for 2 days at dark in layers of wet course filter papers. Extracts were not applied to untreated groups. Treated and untreated seeds were further separated into two groups, i.e. incubation with or without copper. In our previous study, we determined the effective copper sulphate $\left(\mathrm{CuSO}_{4} \cdot 5 \mathrm{H}_{2} \mathrm{O}\right)$ concentration $\left(\mathrm{EC}_{50}\right)$ for tomato as $30 \mathrm{ppm}$ [13]. $\mathrm{EC}_{50}(30 \mathrm{ppm})$ were applied to copper stress groups. All the experimental groups were incubated at $23-25{ }^{\circ} \mathrm{C}$, with $50 \pm 5 \%$ relative humidity, and a photoperiod of 16/8 h (day/night) in growth chamber (Sanyo, Japan) for 7 days. After incubation period, roots were sampled for further analysis.

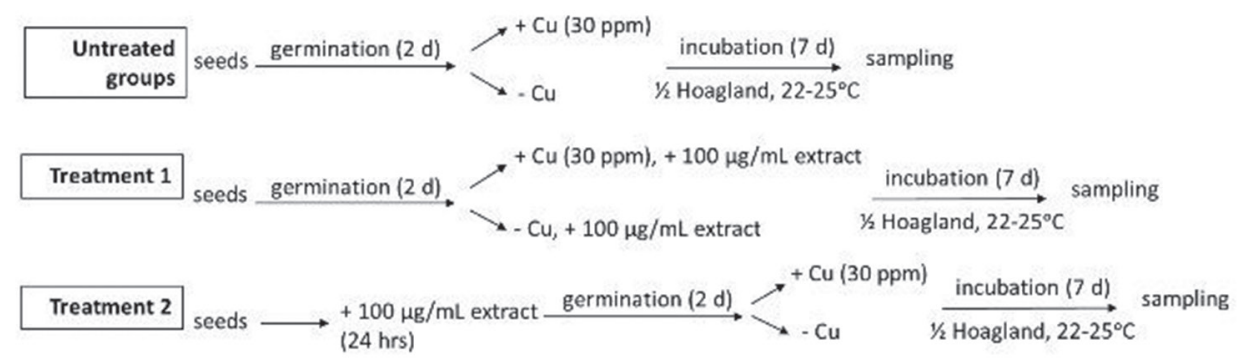

Fig. 1. Experimental setup. Treatment 1 contained $100 \mu \mathrm{g} \mathrm{mL}^{-1}$ jute or nettle extracts in the Hoagland's solution. In the treatment 2 , seeds were pre-soaked into $100 \mu \mathrm{g} \mathrm{mL}^{-1}$ jute or nettle extract solutions prior to germination. Untreated groups were not treated with extracts. $+\mathrm{Cu}$; copper exposure $(30 \mathrm{ppm}),-\mathrm{Cu}$; no copper exposure

\section{Determination of lipid peroxidation}

Lipid peroxidation was assayed by determining the amount of malondialdehyde (MDA), a product of lipid peroxidation [28]. Absorbance was recorded at 532 and $600 \mathrm{~nm}$ against thiobarbituric acid (Sigma) in trichloroacetic acid (Sigma) after incubation at $96{ }^{\circ} \mathrm{C}\left(\varepsilon=155 \mathrm{mM}^{-1} \mathrm{~cm}^{-1}\right)$.

\section{Hydrogen peroxide contents}

The method of Bernt and Bergmeyer [4] was used to determine the $\mathrm{H}_{2} \mathrm{O}_{2}$ content. Samples were assayed in peroxidase reagent containing peroxidase (Sigma) and $o$-dianisidine (Sigma) in potassium phosphate buffer. Absorbance was measured at $436 \mathrm{~nm}\left(\varepsilon=39.4 \mathrm{mM}^{-1} \mathrm{~cm}^{-1}\right)$. 


\section{Determination of ascorbate peroxidase $(A P X)$ and catalase (CAT) activities}

Root samples were homogenized with mortar and pestle in liquid nitrogen. Total protein amount in supernatants were determined according to Bradford method [5]. For determination of APX activity [32], $50 \mu \mathrm{g}$ of total protein was added to assay solution containing ascorbate (Asc; Sigma), and reaction was initiated by addition of $\mathrm{H}_{2} \mathrm{O}_{2}$. Decrease in the absorbance of ascorbate was recorded at $290 \mathrm{~nm}$ for $3 \mathrm{~min}$ against assay solution $\left(\varepsilon=2.8 \mathrm{mM}^{-1} \mathrm{~cm}^{-1}\right)$. For determination of CAT activity [6], $50 \mu \mathrm{g}$ of total protein was added, and the reaction was initiated by addition of $\mathrm{H}_{2} \mathrm{O}_{2}$. Decrease in the absorbance of $\mathrm{H}_{2} \mathrm{O}_{2}$ was recorded at $240 \mathrm{~nm}$ for 3 min against assay solution $\left(\varepsilon=39.4 \mathrm{mM}^{-1} \mathrm{~cm}^{-1}\right)$.

\section{Alkaline comet assay (Alkaline single cell gel electrophoresis; SCGE)}

Nuclei were isolated from roots of the seedlings by chopping root tips in $250 \mu \mathrm{L}$ of ice-cold $0.2 \mathrm{M}$ Tris $\mathrm{pH} 7.5$ containing $4 \mathrm{mM} \mathrm{MgCl}$ and $0.5 \% \mathrm{w} / \mathrm{v}$ Triton X-100 on a watch glass on ice [33]. Twenty five $\mu \mathrm{L}$ of nuclear suspension was mixed with $25 \mu \mathrm{L}$ of $1 \%(\mathrm{w} / \mathrm{v})$ low melting point agarose (Aldrich, USA), and added on to the slides coated with $1 \%(\mathrm{w} / \mathrm{v})$ normal melting point agarose (Aldrich). Slides were incubated in electrophoresis buffer ( $300 \mathrm{mM} \mathrm{NaOH}, 1 \mathrm{mM}$ EDTA disodium salt; $\mathrm{pH}>13)$ for $20 \mathrm{~min}$ at dark, and electrophoresis was run at $24 \mathrm{~V} \mathrm{(300} \mathrm{mA)} \mathrm{for} 30 \mathrm{~min}$. After neutralization, slides were stained with $2 \mu \mathrm{g} \mathrm{mL}{ }^{-1}$ ethidium bromide (Aldrich), and observed under florescence microscope (Nicon, Eclipse 600, Japan). A free software (OpenComet, ImageJ, National Institutes of Health, USA) was employed for image analysis. Tail moment (TM) was used as the end point measure of DNA damage. A minimum of three SCGE slides were prepared for each replicate and in total, a minimum of 100 nuclei were analysed per experimental group.

\section{Statistical analysis}

All data are expressed as mean \pm standard error of the means (SEM), and derived from at least four replicates. All statistical analysis was performed using SPSS 20 Software (SPSS Inc., USA). Mean difference between treatment groups were statistically evaluated by one-way ANOVA analysis at the 0.05 level, and post-hoc Tukey analyses were performed to identify significant differences among groups. 


\section{RESULTS}

\section{Effect of copper and extracts on root growth}

After 7 days of incubation in the presence of copper, growth of tomato roots were inhibited in all experimental groups tested (Fig. 2a). Pre-soaking of seeds with nettle extract caused $20 \%$ increase in root length under unstressed condition $(P<0.05)$. $0.05 \%$ DMSO $(\mathrm{v} / \mathrm{v})$ was tested to eliminate solvent effect, and it had no effect on root growth.

a)

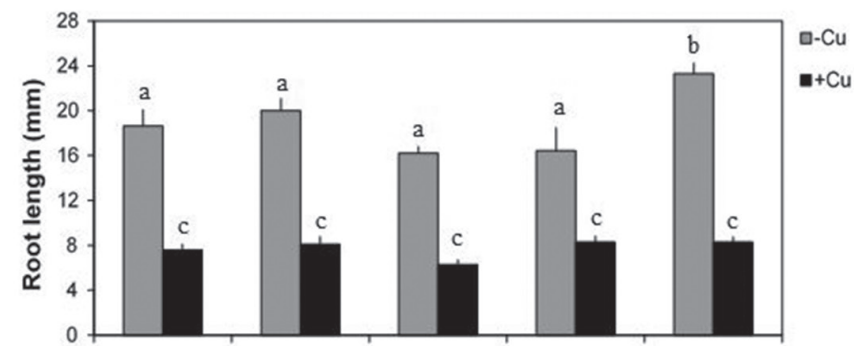

b)

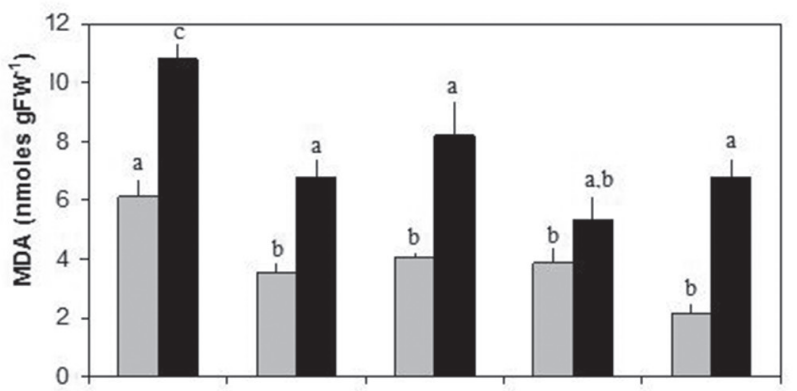

c)

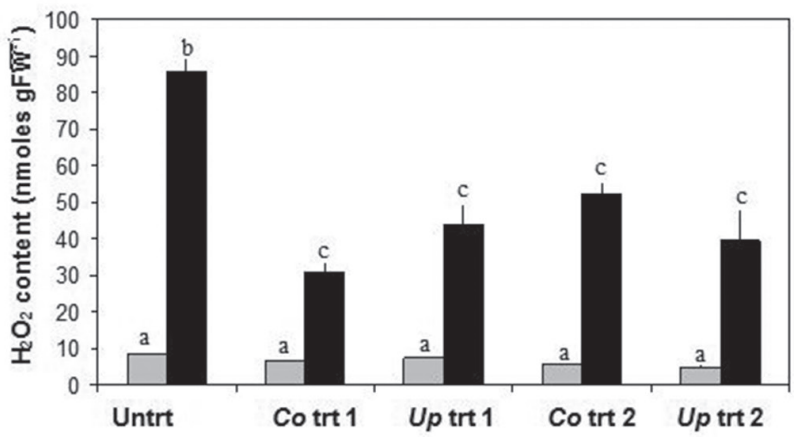

Fig. 2. Effect of copper and extracts on a) the root length of tomato seedlings, b) malondialdehyde (MDA) levels, and c) hydrogen peroxide content of tomato seedlings. Mean values were obtained from 4, 6 and 4 replicates, respectively. Different letters represent significant difference between groups with $P<0.05$. Untrt; untreated, Co trt 1; Corchorus olitorius treatment 1, Up trt; Urtica pilulifera treatment 1, Co trt 2; Corchorus olitorius treatment 2; Up trt 2; Urtica pilulifera treatment 2, $+\mathrm{Cu}$; copper exposure, $-\mathrm{Cu}$; no copper exposure 


\section{Extracts provided protection against oxidative damage}

According to Fig. 2b, extract treatments significantly reduced the basal lipid peroxidation level of the seedlings. Lipid peroxidation of extract treated unstressed groups significantly decreased $(P<0.05)$. MDA level of the extract treated copper stress groups was significantly lower than that of the respective untreated groups. $0.05 \%$ DMSO (v/v) was tested to eliminate solvent effect, and it had no effect on lipid peroxidation. $\mathrm{H}_{2} \mathrm{O}_{2}$ levels significantly increased due to copper stress $(P<0.05)$ (Fig. 2c). However, $\mathrm{H}_{2} \mathrm{O}_{2}$ contents of the extract treated copper stress groups were significantly lower than in the respective untreated groups.

\section{Alterations in antioxidant enzyme activity levels}

APX activity of the untreated group significantly increased $(P<0.05)$ under copper stress (Fig. 3a). However, APX activity remained at unstressed levels in extract treated copper stressed groups $(P<0.05)$. Copper stress caused significant increase in
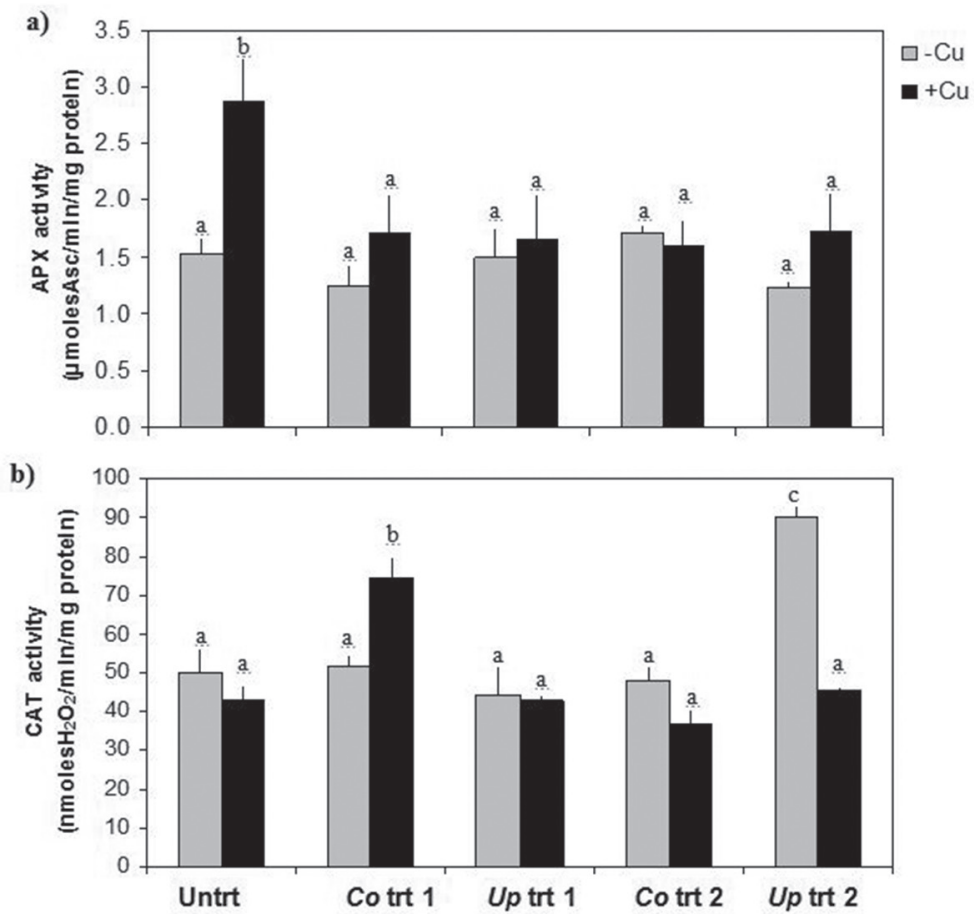

Fig. 3. Effect of copper and extracts on a) ascorbate peroxidase (APX) activity, and b) catalase (CAT) activity levels of tomato seedlings. Mean values were obtained from at least 4 independent replicates. Different letters represent significant difference between groups with $P<0.05$. Untrt; untreated, Co trt 1; Corchorus olitorius treatment 1; Up trt; Urtica pilulifera treatment 1, Co trt 2; Corchorus olitorius treatment 2; Up trt 2; Urtica pilulifera treatment 2, $+\mathrm{Cu}$; copper exposure, $-\mathrm{Cu}$; no copper exposure 
CAT activity of jute treated seedlings when compared to its respective unstressed levels (Fig. 3b). In addition, pre-soaking of seeds to nettle extract enhanced CAT activity of the seedlings when compared to untreated seedlings.

\section{Extracts provided protection against copper induced DNA damage}

Image analysis of Comet assay measures the amount of DNA in the head and in the tail (Fig. 4a). Results of the Comet assay (Fig. 4b), demonstrated copper induced DNA damage in root nuclei of untreated tomato seedlings. 0.05\% DMSO (v/v) was tested to eliminate solvent effect, and it had no effect on DNA damage. DNA damage in root nuclei of all extract treated copper stressed groups were significantly $(P<0.05)$ lower than the untreated group (Fig. 4b). TM of the copper exposed treatment 2 groups were even closer to their respective unstressed levels.

a)

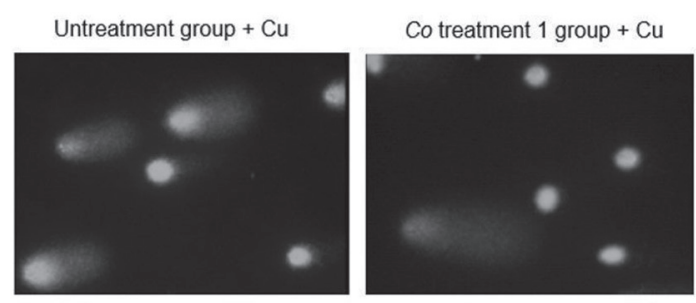

b)

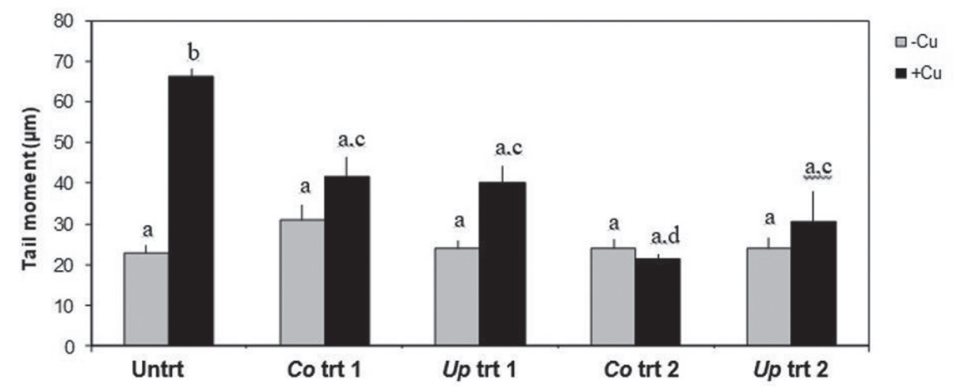

Fig. 4. a) A representative micrographs of Comet analysis, and b) effect of copper and extracts on the mean tail moments (TM) obtained by alkaline Comet assay of the root nuclei. Mean values were obtained from 4 replicates, and 3 SCGE slides for each replicate. Different letters represent significant difference between groups with $P<0.05$. Untrt; untreated, Co trt 1; Corchorus olitorius treatment 1; Up trt; Urtica pilulifera treatment 1, Co trt 2; Corchorus olitorius treatment 2; Up trt 2; Urtica pilulifera treatment 2, $+\mathrm{Cu}$; copper exposure, $-\mathrm{Cu}$; no copper exposure 


\section{DISCUSSION}

The potential use of plant derived non-toxic eco-friendly extracts as seed protectants and disinfectants may be an approach against seed-borne and seed-transmitted bacterial diseases [24]. We detected high antibacterial activity of jute and nettle extracts against Clavibacter michiganensis subsp. michiganensis, the causative agent of bacterial cancer disease of tomato $[13,20]$. Most plants possess allelochemicals which affect seed germination, growth and development of other plants in an ecologically relevant context. On the other hand, treatment of seeds prior to germination (pretreatment) with organic or inorganic compounds and plant growth regulators may decrease germination time, increase germination rate and uniformity, enhance antioxidant response, and increase abiotic stress tolerance, e.g. salt and drought $[14,16]$. There is now emerging evidence for the concept of priming between plant species, which originated from the release of volatile organic compounds (VOC) by plants [3]. Kessler et al. [19] provided the first evidence on the role of priming-inducing signals between plant species by demonstrating VOCs released from Artemesia tridentate, which primed nearby tobacco plants for accelerated production of trypsin proteinase inhibitors concomitant with lower total herbivore damage. Concordantly, we have previously tested the effects of jute and nettle extracts on tomato germination when applied at biologically relevant bacterial inhibitory concentrations. We observed decreased mean germination time (MGT), increased germination efficiency (GE), increased fresh weight $(\mathrm{FW})$ and root/shoot ratio following the treatment of tomato seeds with $C$. olitorius seed extracts prior to germination. Similarly, treatment of tomato seeds with $U$. pilulifera seed extracts prior to germination yielded decreased MGT, increased germination index, GE, final germination percentage, FW, and root and shoot lengths [11].

Enzymatic quenching of ROS, lowered cytoplasmic content, and detoxification through the metal chelators are among the tools against copper toxicity defence of plants [9]. Excess $\mathrm{Cu}^{2+}$ was shown to reduce the root biomass more drastically than the shoot biomass [21]. It was related to the detainment of a very large proportion of the absorbed $\mathrm{Cu}^{2+}$ in the roots, and its low rate translocation to the shoot. In the present study, $30 \mathrm{ppm} \mathrm{Cu}{ }^{2+}$ application caused reduction in root growth of seedlings. Previously, we also demonstrated that $30 \mathrm{ppm} \mathrm{Cu}^{2+}$ application caused an approximate $65 \%$ reduction in the mitotic index of tomato root tip cells [13]. Interestingly, an increase in root growth (20\%) was attained with pre-soaking seeds with the nettle extract. Exogenously supplied plant polyphenols found in the extracts may induce the biosynthesis of genes and cell division via hormonal or intracellular signalling, such as auxins and ethylene.

Two of the parameters to assess copper induced oxidative stress are lipid peroxidation and $\mathrm{H}_{2} \mathrm{O}_{2}$ accumulation. MDA levels of extract treated groups was significantly decreased. So, extract treatments not only lowered copper induced oxidative damage with respect to untreated group, but also decreased the basal lipid peroxidation levels of the roots. All copper stressed treatment groups had accumulated less $\mathrm{H}_{2} \mathrm{O}_{2}$ compared to the untreated group, which is an indication of the detractive impact of 
extracts against copper induced ROS. Phenolics and flavonoids, in particular, stabilize membranes by decreasing membrane fluidity, prevent diffusion of free radicals, and restrict peroxidative reaction by preventing the access of molecules that induce oxidative damage to the hydrophobic region of the bilayer $[2,26]$.

Balance of SOD, GPX, APX, and CAT is important for the suppression of toxic ROS levels in a cell. APX has a higher affinity for $\mathrm{H}_{2} \mathrm{O}_{2}(\mu \mathrm{M}$ range) than CAT (mM range), and CAT is only present in peroxisomes [27]. Therefore, APX act as a buffer zone to control the overall level of ROS that reaches different cellular compartments during stress. This is supported by the remarkably higher APX activity than CAT activity in all groups studied. In fact, we previously reported increased APX activity in roots and leaves of cold stressed and unstressed $\mathrm{H}_{2} \mathrm{O}_{2}$ acclimated plants when compared to control and non-acclimated tomato plants [12]. In the case of the present study, increase in APX activity levels was alleviated due to extract treatments. This may be interpreted as an indication of lower cellular stress as also evidenced by other end-points. Interestingly, jute extract treatment significantly enhanced CAT activity under copper stress which also seems to correlate with the highly reduced $\mathrm{H}_{2} \mathrm{O}_{2}$ levels in this group. In addition, nettle extract treatment prior to germination enhanced CAT activity of the seedlings, which may also correlate to the lower lipid peroxidation level of unstressed seedlings.

One of the quantitative parameters to measure DNA damage in plants is the Comet assay. DNA damage was significantly increased in root nuclei of untreated seedlings under copper stress. ROS, which is produced due to metal exposure, which induces DNA damage via DNA strand breaks. Alternatively, metals themselves or ROS may irreversibly bind/damage to proteins involved in DNA replication, repair and transcription, which in turn leads to damage at nucleic acid level $[23,30]$. Our results show that extract treatments protected cells against copper induced DNA damage.

Chelation of the metal by a ligand and, in some cases, the subsequent compartmentalization of the ligand-metal complex is another mechanism of the elimination of copper toxicity. Ligands are phytochelatins (metal-binding peptides), metallothioneins (low molecular weight metal-binding molecules), and organic acids (e.g. citrate and malate). Plant polyphenols are found in all parts of plants such as leaves, fruits, seeds, roots and bark, and possess an ideal structural chemistry for free radical scavenging activity and metal chelation [25]. So, in terms of elimination of copper toxicity by metal chelation, extracellular $\mathrm{Cu}^{2+}$ ions might be stabilized by the polyphenols in the treatment groups. Seed extracts might be the source of organic acids for $\mathrm{Cu}^{2+}$ chelation. Compounds of the extracts taken by cells may induce the expression of genes related with major thiol and non-thiol compounds and metal chelation [1] or extracts may affect the phenolic compound metabolism of tomato, in addition to the possible changes in expression pattern of genes of the antioxidant defence.

Urticaceae species have secondary metabolites that are mainly polyphenolic compounds [17]. According to the HPLC-TOF-MS analysis, jute seed extract contains gallic acid, vanillic acid, rosmarinic acid, salicylic acid (SA), and quercetin (Table 1). Amongst, vanillic acid was found to be the most abundant phenolic acid. Vanillic acid isolated from Chenopodium murale has been evaluated for its allelopathic potential 
on tomato, and enhancement of catalase, peroxidase, superoxide dismutase, and polyphenol oxidase activities were observed [10]. Saleh and Madany [29] demonstrated that coumarin pretreatment of seeds enhanced the activity of phenylalanine ammonia lyase, and phenolics, in particular vanillic acid, accumulated in wheat seedlings. Flavonoids, like quercetin, are known to form complexes with heavy metals, which enhance defensive response of plants to heavy metal stress [26]. The study of Keilig and Ludwig-Müller [18] has provided evidence that exogenous naringenin and quercetin were able to restore partially seedling growth under heavy metal stress in both wild type and flavonoid deficient mutants of Arabidopsis thaliana. Exogenous SA application was correlated to abiotic tolerance of plants including heavy metal stress [31].

Finally, one of the recent ideas on the molecular aspect of pretreatment is the epigenetic regulatory effects of polyphenols via chromatin modifications, which may also explain the hardening effects of extracts. Seed pretreatment may provide a faster activation of the defence related genes by imprinting a memory for systemic acquired immunity [7].

In conclusion, considering the MDA and Comet analysis as cytotoxic and cytogenetic end points, respectively, treatment of seeds with either jute or nettle extracts for $24 \mathrm{~h}$ prior to germination seems to be more effective. Enhancement of root length and CAT activity in nettle treated seeds would be an additional remark. In addition, shortterm seed treatment prior to germination may provide a more feasible and practical application modality considering their potential applications as seed protectants and disinfectants against phytopathogenic bacteria. Furthermore, implications of the present study can be summarized as follows: a) these applications can be considered as seed priming to increase heavy metal tolerance, $b$ ) seedling treatments may provide early disease control with protection against copper induced toxicity which may have a potential use with copper compounds, and c) to our knowledge, this is the first study demonstrating the protective effects of plant extract treatments against copper stress of tomato seedlings, applied as seed treatment prior to germination or supplied during seedling development.

\section{ACKNOWLEDGEMENTS}

This study was supported by the Baskent University Research Fund. Assoc. Prof. Dr. Evren Cabi is greatly acknowledged for the authentication of the plant materials. We also acknowledge Department of Medical Biochemistry, Faculty of Medicine, Baskent University for lyophilization process.

\section{REFERENCES}

1. Anjum, N. A., Hasanuzzaman, M., Hossain, M. A., Thangavel, P., Roychoudhury, A., Gill, S. S., Rodrigo, M. A. M., Adam, V., Fujita, M., Kizek, R., Duarte, A. C., Pereira, E., Ahmad, I. (2015) Jacks of metal/metalloid chelation trade in plants - an overview. Front. Plant Sci. 6, 192.

2. Arora, A., Byrem, T. M., Nari, M. G., Strasburg, G. M. (2000) Modulation of liposomal membranes fluidity by flavonoids and isoflavonoids. Arch. Biochem. Biophys. 373, 102-109. 
3. Beckers, G. J. M., Conrath, U. (2007) Priming for stress resistance: from the lab to the field. Curr. Opin. Plant Biol. 10, 425-431.

4. Bernt, E., Bergmeyer, H. U. (1974) Inorganic peroxidasses. In: Bergmeyer, H. U. (ed.) Methods of Enzymatic Analysis. CRC Press, Boca Raton, pp. 2246-2248.

5. Bradford, M. M. (1976) A rapid and sensitive method for the quantitation of microgram quantities of protein utilizing the principle of protein-dye binding. Anal. Biochem. 72, 248-254.

6. Chance, B., Mahly, A. C. (1995) Assay of catalases and peroxidases. Methods Enzymol. 2, $764-817$.

7. Conrath, U. (2011) Molecular aspects of defence priming. Trends Plant Sci. 16(10), 524-531.

8. Doncheva, S., Nicolov, B., Ogneva, V. (1996) Effect of copper excess on the morphology of the nucleus in maize root meristem cells. Physiol. Plantarum 96, 118-122.

9. Ducic, T., Polle, A. (2005) Transport and detoxification of manganese and copper in plants. Braz. J. Plant Physiol. 17, 103-112.

10. Ghareib, H. R. A., Abdelhamed, M. S., Ibrahim, O. H. (2010) Antioxidative effects of the acetone fraction and vanillic acid from Chenopodium murale on tomato plants. Weed Biol. Manag. 10, 64-72.

11. İşeri, Ö. D., Körpe, D. A., Sahin, F. I., Haberal, M. (2012) Evaluation of plant extracts of high antibacterial activity against Clavibacter michiganensis subsp. michiganensis for allelopathic effect on tomato seed germination. New Biotech. 29, 186.

12. İşeri, Ö. D., Körpe, D. A., Sahin, F. I., Haberal, M. (2013) Hydrogen peroxide pretreatment of roots enhanced oxidative stress response of tomato under cold stress. Acta Physiol. Plantarum 35, 1905-1913.

13. İşeri, Ö. D., Körpe, D. A., Yurtcu, E., Sahin, F. I., Haberal, M. (2011) Copper-induced oxidative damage, antioxidant response and genotoxicity in Lycopersicum esculentum Mill. and Cucumis sativus L. Plant Cell Rep. 30, 1713-1721.

14. İşeri, Ö. D., Sahin, F. I., Haberal, M. (2014) Sodium chloride priming improves salinity response of tomato (Lycopersium esculentum Mill.) at seedling stage. J. Plant Nutr. 37, 374-392.

15. İşeri, Ö. D., Yurtcu, E., Sahin, F. I., Haberal, M. (2013) Corchorus olitorius (jute) extract induced cytotoxicity and genotoxicity on human multiple myeloma cells (ARH-77). Pharma. Biol. 51, 766-770.

16. İşeri, Ö. D., Körpe, D. A., Yurtcu, E., Sahin, F. I., Haberal, M. (2015) Seed priming to increase germination, drought tolerance and yield of cucumber. Acta Adv. Agr. Sci. 3, 42-53.

17. Kavalali, G., Tuncel, H. (1997) Anti-inflammatory activities of Urtica pilulifera. Pharma. Biol. 35, $138-140$.

18. Keilig, K., Ludwig-Müller, J. (2009) Effect of flavonoids on heavy metal tolerance in Arabidopsis thaliana seedlings. Bot. Studies 5, 311-318.

19. Kessler, A., Halitschke, R., Diezel, C., Baldwin, I. T. (2006) Priming of plant defense responses in nature by airborne signaling between Artemisia tridentata and Nicotiana attenuate. Oecologia 148, 280-292.

20. Körpe, D. A., İşeri, Ö. D., Sahin, F. I., Cabi, E., Haberal, M. (2012) High-antibacterial activity of Urtica spp. seed extracts on food and plant pathogenic bacteria. Int. J. Food Sci. Nutr. 64, 355-362.

21. Lequeux, H., Hermans, C., Lutts, S., Verbruggen, N. (2010) Response to copper excess in Arabidopsis thaliana: Impact on the root system architecture, hormone distribution, lignin accumulation and mineral profile. Plant Physiol. Biochem. 48, 673-682.

22. Lidon, F. C., Ramalho, J., Henriques, F. S. (1993) Copper inhibition of rice photosynthesis. J. Plant Physiol. 142, 2-17.

23. Lin, A. J., Zhang, X. H., Chen, M. M., Cao, Q. (2007) Oxidative stress and DNA damages induced by cadmium accumulation. J. Environ. Sci. (China) 19, 596-602.

24. Lo Cantore, P., Iacobellis, N. S., De Marco, A., Capasso, F., Senatore, F. (2004) Antibacterial activity of Coriandrum sativum L. and Foeniculum vulgare Miller var. vulgare (Miller) essential oils. J. Agric. Food Chem. 52, 7862-7866.

25. Mathew, S., Abraham, T. E. (2006) Studies on the antioxidant activities of Cinnamon (Cinnamomum verum) bark extracts through in vitro models. Food Chem. 94, 520-528. 
26. Michalak, A. (2006) Phenolic compounds and their antioxidant activity in plants growing under heavy metal stress. Pol. J. Environ. Stud. 15, 523-530.

27. Mittler, R. (2002) Oxidative stress, antioxidants and stress tolerance. Trends Plant Sci. 7, 405-410.

28. Ohkawa, H., Ohishi, N., Yagi, K. (1979) Assay for lipid peroxides in animal tissues by thiobarbituric acid reaction. Anal. Biochem. 95, 351-358.

29. Saleh, A. M., Madany, M. M. Y. (2015) Coumarin pretreatment alleviates salinity stress in wheat seedlings. Plant Physiol. Biochem. 88, 27-35.

30. Seth, C. S., Misra, V., Chauhan, L. K. S., Singh, R. R. (2008) Genotoxicity of cadmium on root meristem cells of Allium cepa: cytogenetic and Comet assay approach. Ecotoxicol. Environ. Safety $71,711-716$.

31. Shi, Q., Bao, Z., Zhu, Z., Ying, Q., Qian, Q. (2006) Effects of different treatments of salicylic acid on heat tolerance, chlorophyll fluorescence and antioxidant enzyme activity in seedlings of Cucumis sativa L. Plant Growth Reg. 48, 127-135.

32. Wang, S. Y., Jiao, H., Faust, M. (1991) Changes in ascorbate, glutathione and related enzyme activities during thiodiazuran-induced bud break of apple. Plant Physiol. 82, 231-236.

33. Yildiz, M., Cigerci, İ. H., Konuk, M., Fidan, A. F., Terzi, H. (2009) Determination of genotoxic effects of copper sulphate and cobalt chloride in Allium cepa root cells by chromosome aberration and Comet assays. Chemosphere 75, 934-938. 